\title{
The Acadian plutonic rocks of New Brunswick
}

\author{
L.R. Fyffe, New Brunswick Department of Natural Resources, \\ Mineral Resources Branch, P.O. Box 6000, Fredericton, New Brunswick, Canada, E3B 5H1
}

G.E. Pajari, Jr. and M.E. Cherry*

Department of Geology, University of New Brunswick, P.O. Box 4400, Fredericton, New Brunswick, Canada, E3B $5 A 3$

\begin{abstract}
Extensive bimodal plutonism accompanied and followed the Acadian deformation in New Brunswick. These Acadian plutons define a Central Plutonic Belt, which is largely confined to a terrain with an Acadian trend of $030^{\circ}$, and a Southern Plutonic Belt, which occurs within a structural province with an Acadian and Varfscan trend of $060^{\circ}$.

It has been possible to classify the Acadian plutons north of the Avalonian Platform according to their structures, textures, fleld relationships, mineralogy, and chemical characteristics; supplemented by radiom metric age dates. Plutonic rock types include: A-B a mafic-felsic association; C - syntectonic tonalite and granodiorite; D - muscovite-bearing; F - megacrystic granitoids; B - equigranular biotite granites; and $\mathrm{E}$ and G - 'transitional' granttes.

The magmatism, regardless of location, follows a common evolutionary trend and appears to comprise a sequence of intrusfons from early Devosian to Carboniferous time with no significant break in the evolution. These characteristics along with the bimodal chemistry and the lack of compositional polarity suggest that the development of these Acadian plutons was not bubduction-related. A time-depeadent process such as radioactive heating of a thickened crust 18 a more probable mechantsm for their genesis.
\end{abstract}

Au Nouveau-Brunswick, la déformation acadienne fut accompagnée puls sulvie d'un plutonisme bimodal très étendu. Ces plutons acadiens définissent une zone intrusive centrale et une zone intrustve méridionale: la premlère se confine en grande partie dans une région qui présente une orientation acadienne de $030^{\circ}$ alors que la seconde se trouve à I'Intérleur d'une province structurale marquée par une ortentation acadienne et varisque de $060^{\circ}$.

Au nord de la plate-forme avalonienne, les plutons acadiens ont pu être classifiés selon leura structures, textures, relations de terrain alns1 que leurs caractérisques minéralogiques et chimfques, le tout étant complété par des datations radiométriques. Les roches intruglves comprennent: A-B une association mafique et felsique; $C$ - une granodiorite et une tonalite syntectoniques; D - roches lntrusives a muscovite; F - granttoides à blotite équigranulaire; et E et G - granites "de transition".

Peu 1mporte l'endroit, on observe une tendance évolutive commune à ce magmatisme qui semble comprendre une sulte d'Intrusions, évoluant sans interruption du Dévonien inférieur au Carbonifère. Ces caractériatiques, en plús de la blmodalité du chimlome et de l'absence de polarité de composition, ouggèrent que ces plutons acade1ns ne furent pas formés par subduction. Pour engendrer ceux-c1, un processus lie au temps, tel que le réchauffement radioactif d'une croûte qui s'est épalssle, est plus probable.

[Tradult par le journal]

\section{GEOLOGIC SETTING}

The pre-carboniferous rocks north of the exposed Avalonian Platform can be divided into four tectonostratigraphic zones (Ruitenberg et al. 1977). These are, from southeast to northwest, the Fredericton Trough, the Miramichi Massif, the Elmtree Inlier and the Matapedia Basin (Fig. 1). The plutonic rocks of the Central Plutonic Belt are mainly restricted to the Miramichi Massif, while those of the southern Plutonic Belt occur along the southern margin of the Fredericton Trough.

Matapedia Basin

The oldest rocks exposed in the Matapedia Basin are Caradocian clastic turbidites containing abundant volcanic detritus. Upper Ordovician (Ashgillian) to Lower Silurian calcareous flysch conformably overlies the clastic sequence and indicates peneplanation of the source area by this time.

The calcareous flysch is conformably overlain by Lower Silurian to Lower Devonian (Siegenian-Emsian) clastic sedimentary rocks to the northwest (St. Peter 1978) and by a suite of volcanic rocks ranging in age from late Silurian to early Devonian (Geóinnian) along a northeasterly trending belt localized along the border of the Matapedia Basin with the Miramichi Massif. North of the Rocky Brook Millstream Fault, the late Silurian

*Present Address: Ontario Geological Survey, 77 Grenville St., Toronto Ontario

MARITIME SEDIMENTS AND ATLANTIC GEOLOG

$17,23-36(1981)$ 
volcanics are a bimodal calc-alkaline to mildly alkaline suite with a gap from $58 \%$ to $66 \% \mathrm{SiO}_{2}$ (Fig. 2a), whereas the early Devonian rocks have an unimodal trend with abundant intermediate rocks and minor rhyolite (Fig. 2b). Only early Devonian volcanics occur south of the fault and, although no chemical analyses are available, these appear to be bimodal, with the volume of rhyolite increasing from the northwest to southeast as the margin of the Massif is approached.

Apart from its southeastern margin, igneous rocks are virtually absent from the Matapedia Basin though erosion has exposed it to considerable depth; this perhaps indicates a thin underlying crust to the Basin. Rocks within the Basin have undergone one period of penetrative Acadian deformation. accompanying metamorphism is subgreenschist grade except along the southeastern margin where it reaches the greenschist facies.

A lengthy period of instability along the Basin's southeastern margin is indicated by abundant volcanic activity and a varied geologic history. In the north, post-Taconian transgression of the Matapedia sea over the margin of the Miramichi Massif is marked by the presence of Upper Silurian (Ludlovian) conglomerate lying unconformably on ordovician mafic volcanic rocks. Further to the southwest, Lower Devonian volcanic rocks and interbedded quartzite of the Matapedia Basin are faulted against sillimanite-grade Cambroordovician rocks of the Miramichi Massif. Plant-bearing Devonian sedimentary rocks overlying the volcanics contain abundant metamorphic detritus eroded from the Massif. This erosion presumably accompanied faulting and uplift of the Massif which preceded emplacement of early Acadian intru- sions into the southeastern margin of the Basin (Fyffe and Cormier, 1979).

In the south, Ashgillian calcareous flysch of the Matapedia Basin is in fault contact with Cambro-Ordovician quartz wacke of the Massif. A northwest-trending graben transecting the Massif contains Lower Devonian volcanics that overlie silurian calcareous sandstone. Quartzite-pebble conglomerate with a calcareous matrix is locally preserved lying unconformably on the Taconian terrain (Lutes 1979).

\section{Elmtree Intier}

An uplifted block to the north of the Miramichi Massif consists of deformed gabbro, amphibolite, sheeted dikes, peridotite and minor plagio-granite overlain by pillow. basalt of lower greenschist facies (Rast and Stringer 1980). Caradocian feldspathic and quartzose turbidites overlie the basalt and in turn are overlain unconformably by Lower Silurian conglomerate.

The ophiolite suite of the Elmtree Inlier represents a remnant of the Ordovician Iapetus Ocean (Pajari et al. 1977). Seventy kilometers to the northeast, across the Bay of Chaleur, the pre-Caradocian Macquereau Group of the Gaspé Peninsula has been identified as the rise prism of the North American continent (St. Julien and Hubert 1975). Therefore, the suture of the Iapetus Ocean lies between Gaspé and the Miramichi Massif.

\section{Miramichi Massif}

The oldest rocks exposed in the Massif are a thick sequence of quartz wacke, quartzite and slate (lower Tetagouche Group) representing a continental rise prism formed off the Avalonian platform (Schenk 1971, Ruitenberg et al. 1977). The quartzose sequence is 


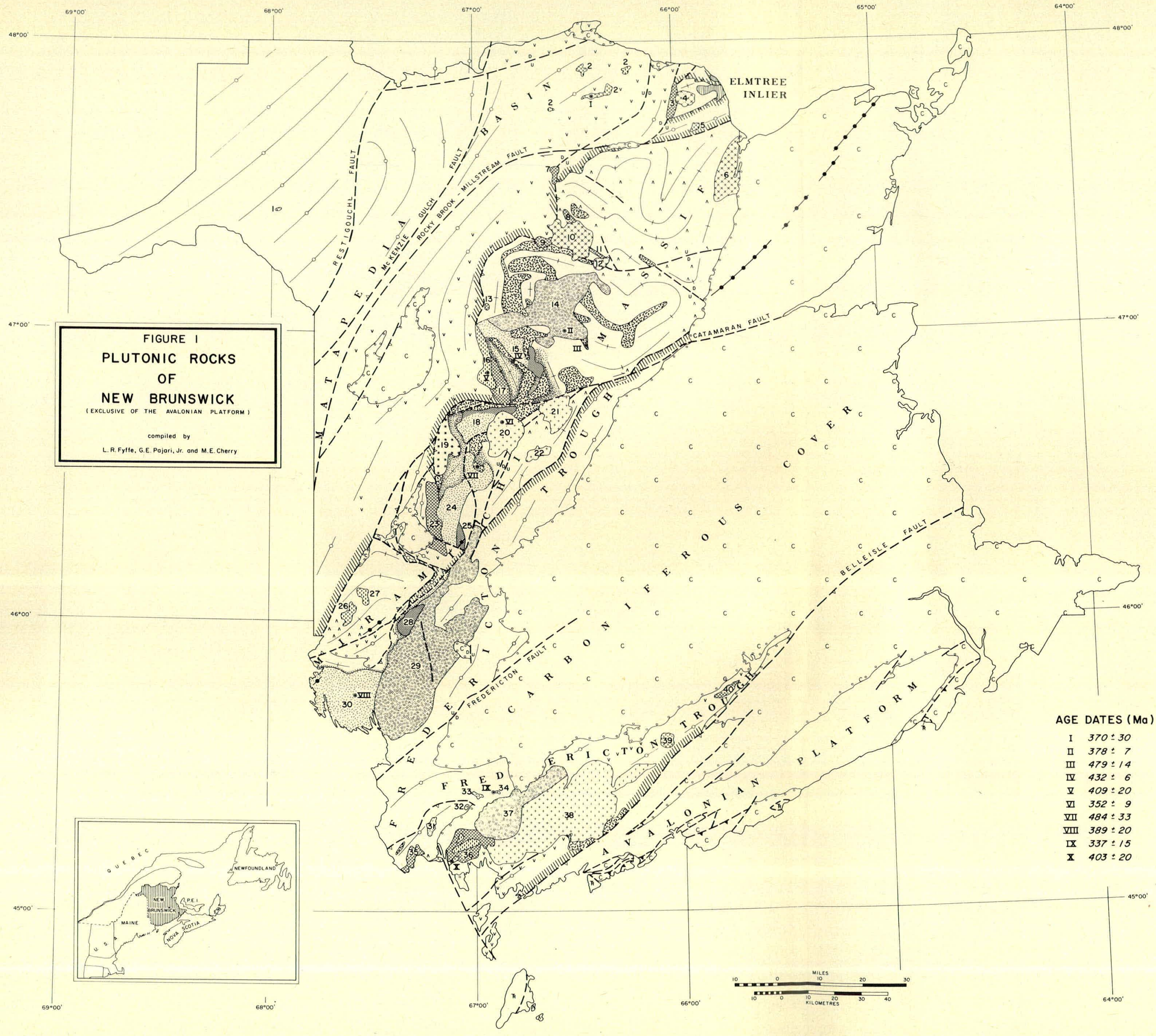

CARBONIFEROUS / TRIASSIC

DEVONIAN / CARBONIFEROUS

H Coorse- grained equigr ronular biofite gronite charocterized by

G W Medium-grained equigranular biotite \pm hornblende granite

F Megocrystic biotitite : hornblende granite (trons granodiorite)

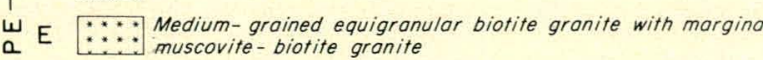

ᄃ D Medium-grained equigranu/ar muscovite- biotite gronite

B 1 . Medium- grained subporphyritic to porphyritic

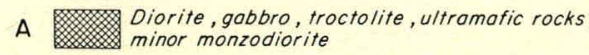

ORDOVICIAN

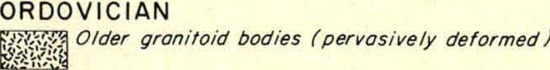

Inintin Ophiolite

, IIIII) Zone boundary

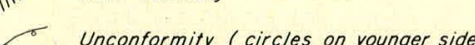

X Taconian cleavage

of Acodian cleavage

1. Sillimonite grode metomorphism

an'w Volcanics, Ordovicicion sabse (lote Triossic)

¿6 Normal foult

Wrench foult

It High-angle reverse foult

at Thrust foult

-II Rb-Sr whole rock age date $\left(t=1.42 \times 10^{-11} \mathrm{yr}\right.$ )

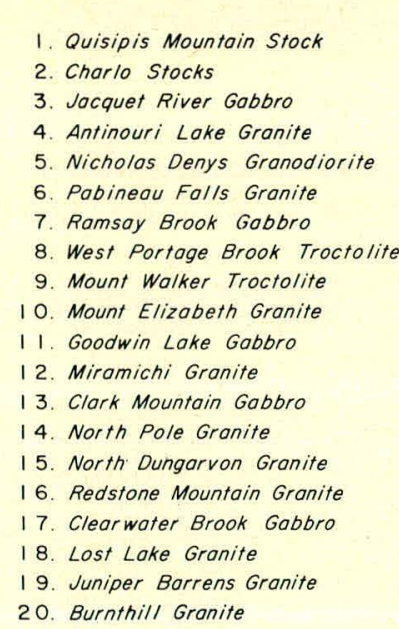

21. Dungarvon Granite

22. Trout Brook Granite
23. Becaguimec Lake Gabbro

24. Noshwook Granite

25. Howard Peak Granodion

26. Gibson Granodiorit

28. Hertfield Tonalite
29. Howkshow Granite

29. Howkshow Granite
30. Skiff Loke Granite

31. Tower Hill Granite

32. Sorre/ Ridge Gronite
33. Pleasont Ridge Granite

33. Pleasant Ridge Grontro
34. Beech Hill Gronite

35. St. Stephen Pluton
36. Bocabec Complex

36. Bocabec Complex
37. Mc Dougall Lake Granodiorita

38. Charlotte Grantire

19. Juniper Borrens Grar
20. Burnthill Granite

40. Stewarton Complex 
in places overlain conformably by a thin calcareous slate containing an early ordovician fauna (Neuman 1968, Fyffe 1976) and elsewhere is overlain unconformably by quartzite pebble conglomerate presumably of early ordovician age. This local unconformity appears related to instability associated with the onset of Ordovician volcanic activity.

The Lower Ordovician calcareous slate and conglomerate are overlain by a sequence of predominantly felsic volcanic rocks and a generally younger Caradocian sequence of mafic volcanic rocks and greywacke (Helmstaedt 1971). Pir7ow lavas interbedded with iron- and manganese-rich slate indicate a marine depositional environment. The abundance of felsic volcanic rocks and associated pervasively deformed granites (Fyffe et $a l$. 1977) suggests in turn that continental crust underlies much of the Ordovician volcanic terrain. The volcanism is interpreted to have been caused by the southeast subduction of oceanic crust along a continental margin represented by the Miramichi Massif (Pajari et al. 1977).

The layered rocks and intrusive older granitoids were polydeformed and metamorphosed from subgreenschist to amphibolite grade and uplifted during the Taconic orogeny, which is related to the closure of the Iapetus Ocean (Bird and Dewey 1970). During the Acadian orogeny, the Massif was intruded by a large volume of magma, mainly of granitic composition (Fig. 2c). Differential uplift of fault blocks and resulting erosion has exposed plutons to various depths along the length of the Massif. Uplift was greatest within the central portion of the Massif along its northwestern margin. Latest movement on prominent east-trending dextral faults post-dates emplace-

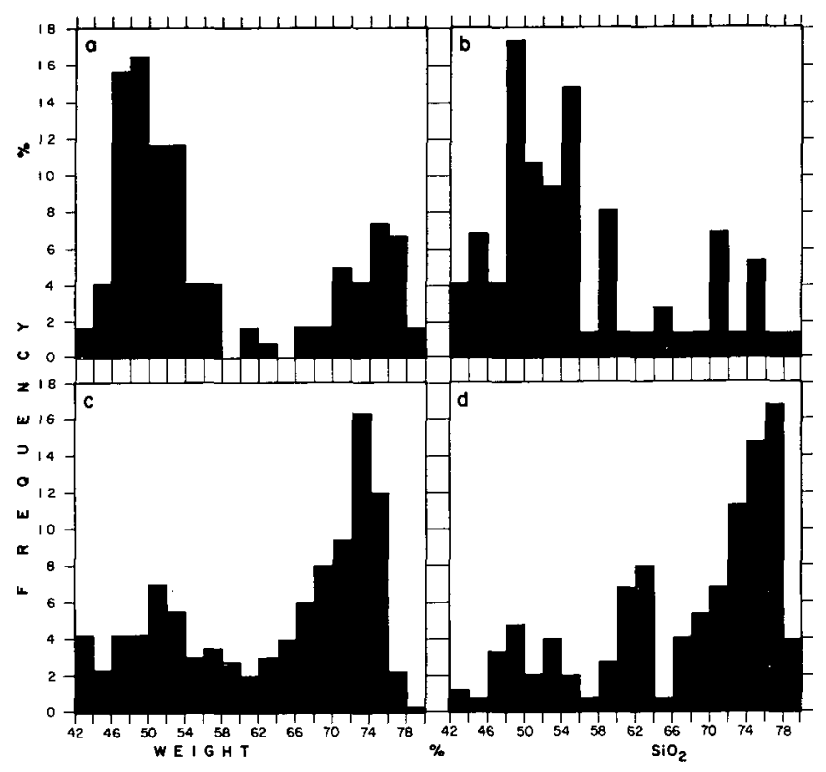

Fig. 2 - $\mathrm{SiO}_{2}$ histograms: a) Silurian volcanics from Matapedia Basin (121. analyses); b) Devonian volcanics from Matapedia Basin north of Rocky Brook Millstream Fault (55 analyses); c) Acadian plutonic rocks from Central Plutonic Belt (257 analyses); d) Acadian plutonic rocks from Southern Plutonic Belt (150 analyses).

ment of the youngest Acadian plutons.

Acadian cleavage within the Fredericton Trough and Matapedia Basin parallels irregularities along the margins of the Miramichi Massif and is only locally developed within the Massif. It, therefore, appears that the Massif acted as a buttress during Acadian deformation. For this reason and because of its complex metamorphic and igneous history we prefer the term Massif rather than Anticlinorium (Rodgers 1970).

\section{Fredericton Trough}

The Fredericton Trough, in fault contact with the southeastern margin of the Miramichi Massif, was the site of turbidite deposition from Wenlock to Ludlow time. The correlation of the lower Cookson 
Formation of southern New Brunswick with the lower Tetagouche Group of the Miramichi Massif (Ruitenberg et al. 1977) suggests that the Cambro-ordovician continental rise sediments covered all the terrain north of the Avalonian Platform to the Matapedia Basin prior to the development of the Fredericton Trough.

Minor pillow basalts occur in the Ordovician rocks of the cookson Formation and more extensive, mainly bimodal (McCutcheon and Ruitenberg, in prep.), volcanism prevailed in late silurian and early Devonian time along the southern margin of the Trough. This younger volcanism is correlatable with the Coastal Belt of New England. The rocks of the Fredericton Trough were deformed during the Acadian Orogeny and were subsequently intruded by the largely bimodal suite of the southern Plutonic Belt (Fig. 2d). Rocks of intermediate composition are of small areal extent (Fyffe 1971).

The Fredericton Trough is interpreted to represent a mature rift that had developed into a turbiditic basin by middle Silurian time and was closed during the Acadian orogeny with attendant polyphase deformation and subgreenschist to greenschist metamorphism. The main Acadian cleavage adjacent to the Miramichi Massif parallels the contact $\left(030^{\circ}\right)$ whereas those against the Avalonian Platform trend $060^{\circ}$. This structural divergence indicates that the basement of the Trough widened to the northeast and acted as an independent crustal segment. The paucity of igneous rocks in the central part of the Trough suggests that the underlying crust was different (thinner?) than that underlying the Miramichi Massif or the boundary between the Trough and the Avalonian Platform.
Second Acadian folds associated with the high angle thrust faults verge to the northwest near the boundary with the Miramichi Massif, whereas second folds along the southern margin of the Trough verge to the south (Ruitenberg et al. 1977).

\section{Summary}

An early Paleozoic continental rise prism extended northward from the Precambrian Avalonian Platform onto the Miramichi Massif. The northern and northwestern boundaries of the Massif are identified as the edge of the Avalonian continent bordering the Iapetus Ocean which lay to the north. The southward subduction of the Iapetus gave rise to the Miramichi bimodal volcanic arc and later, during the closing stages of the ocean, resulted in the Taconian Orogeny of post-Caradocian, pre-Ludlovian age.

The Matapedia Basin remained a depositional site through the closure while the Fredericton Trough evolved, probably through thinning of the continental crust, to become the site of Silurian turbidite deposition. Volcanism, largely bimodal, along the southeastern margin of the Matapedia Basin was nearly contemporaneous with bimodal volcanism during the late Silurian and early Devonian along the southern margin of the Fredericton Trough. The Acadian Orogeny deformed the rocks of the Matapedia Basin and the Fredericton Trough and was accompanied and followed by extensive bimodal plutonic activity in the Miramichi Massif and along the southern border of the Fredericton Trough.

Classification of Acadian Plutons

The major criteria and the resulting distinctions which were used to classify the Acadian Plutons are: 
1) mineralogy - compositional distinction; i.e., mafic from felsic, muscovite \pm biotite from biotite-bearing;

2) character of metamorphic aureole;

3) texture - particularly the identification of the megacrystic type;

4) structure - identification of deformation; and

5) compositional and intrusive relationships between spatially related intrusions identification of Types $A-B$ and D-F associations.

In the application of these criteria, some plutons were found to possess characteristics transitional to the more readily definable types. These were allocated a separate status (Types $E$ and $G$, Fig. 1), and because of their intermediate characteristics, will be described last in the following descriptive section. It should be understood that the classification is based solely on field and petrographic criteria and that the chemical data were used simply to provide additional indices for the classification.

The available data (Table 3) for the individual plutons are variable in detail and quality, a factor which will undoubtedly necessitate future modifications to this scheme. Analyses which represented identifiable minor phases or anomalous mineralogy were eliminated.

Types $A$ and $B$ -

The mafic-felsic association

$A$ : $[3,7,8,9,11,13,17,23,35,40]$;

$B:[1,2,5,16,26,27,36,39]$ *

The mafic plutons (Type A) variable in mineralogy and internal structure. These range from well-defined tholeitic layered intrusions $[8,9,11,35,40]$ with varying iron enrichment trends to ophitic gabbros $[3,7,13]$, some of which contain late amphibole and pegmatitic gabbro $[17,23,36]$. An example of such variation occurs between the st. Stephen [35] and nearby Bocabec [36] intrusions. These plutons were virtually contemporaneous, but the former is a layered intrusion while the latter is characterized by ophitic textures and abundant pegmatites with only a local 35 meter thick subhorizontal cumulate unit, much of which was destroyed by later pegmatization. If these intrusions had a common magmá source, as is probable, the major differences can be attributed to water saturation of the Bocabec gabbroic magma (compare the gabbro analyses 35 and $36 a$, Table 3 ; the former may represent a partial plagioclase cumulate and the latter, a gabbro slightly "metasomatically" enriched in $\mathrm{K}_{2} \mathrm{O}$ by the later granite intrusions). Variation in iron enrichment is illustrated by the contrast between the St. Stephen [35] and Stewarton [40] intrusions (compare analyses 35 and 40 , Table 3). The main episode of mafic intrusion was followed, at least locally, by a minor volume of diabase which intrudes the mafic plutons $[17,35,36,40]$ and some of the earliest of the felsic plutons.

It is evident from Figure 1 that the distribution of mafic and ultramafic intrusions in the central Plutonic Belt is controlled by the faults which bound and segment the Miramichi Massif. Although fault control in the Southern Belt is not self-evident from Figure 1, geologic relations

* Individual Acadian plutons on Figure 1 are identified in the text by numbers in square brackets (See Legend, Figure 1) 
in Maine (Wones 1976, Wones and Stewart 1976) suggests that such a relationship exists there as well.

The felsic rocks (Type B) associated with mafic plutons constitute an apparently diverse group in terms of composition and spatial relationships. These include felsic plutons intruding mafic plutons [16 into 17, the Baring Granite, Maine into 35] minor felsic phases intruding mafic plutons $[2,17,23$, $35,36,40]$ and felsic plutons intruded by minor mafic phases [26, 27]. The occurrence of porphyritic texture, granophyre, and miarolitic cavities attest to the high level emplacement of the Type B plutons. The distinctive character and the chemical variability of the Type B granitoids are illustrated in Figure 3 .

An important feature of the Type $A-B$ association is the common occurrence of minor intermediate rocks. These intermediate rocks have been shown in two cases $[35,36]$ to represent hybrid rocks formed by the reaction of granite magma with gabbro (Fyffe 1971, Butt 1976). Although mobilization of country rock and "backveining" have also been observed $[11,17,35]$, the origin of other intermediate to felsic phases in the ophitic-textured mafic plutons is uncertain.

The extent and grade of the contact metamorphism appear to be primarily dependent on the character of the country rocks. Those mafic plutons intruded into low grade country rocks possess relatively narrow $(<1 \mathrm{~km})$ aureoles which reach pyroxene hornfels assemblages with some minor development of melt phases $[35,36]$. In contrast, those contacts against Cambro-ordovician rocks in the central Miramichi Massif are of sillimanite grade [17I. A similar, though somewhat lower grade, pattern exists for the felsic plutons, suggesting that the heat loss was by conduction into country rocks that were at different pre-intrusion temperatures. The southernmost felsic body in the Bocabec Complex [36], which has no identifiable metamorphic aureole against the Lower Devonian country rocks, is an exception. Here the heat energy is believed to have been dissipated over a large volume of country rock by convecting groundwater.

The Quisipis [1], Nicholas Denys [5] and Hampstead [39] intrusions have been included in the Type $B$ group on textural and mineralogic criteria (cf. analyses 5, 39; Table 3).

Type $C$

Syntectonic tonalite and granodiorite $[15,18,25,28]$

Two intrusions $[25,28]$ ranging in composition from tonalite to granodiorite, possess a weak fabric of aligned plagioclase and hornblende and a general elongate shape which parallels the regional structural trend. Well-developed contact aureoles (cordierite, andalusite, sillimanite) overprint the composite Taconic fabric.

The southeastern portion of the North Dungarvon River Granite [15] and the northern border of the Lost Lake Granite [18] are foliated and contain abundant mafic inclusions. These portions should therefore be included in Type $C$ but further mapping is required to subdivide these plutons.

Mineralogically and chemically, these plutons closely resemble Type B granitoids. The Type C plutons were intruded into a tectonically active deeper level of the Miramichi Massif and are more strained than the nearby Type D or $F$ plutons. These constraints 
suggest an age intermediate between the $B$ and $D$ types, although they may well be contemporaneous with the $B$ type granitoids that were intruded into a tectonically less active environment.

Type $D$

Muscovite-bearing intmusions

$[15,18,24,30,31,33]$

The intrusions with pervasive primary muscovite in the central Plutonic Belt were emplaced into rocks with regional metamorphic fibrolite. Contact aureoles of these plutons in the central Miramichi Massif $[18,24]$ contain robust sillimanite, in addition to fibrolite (that is distinct from the deformed regional metamorphic fibrolite of the area) up to $1 \mathrm{~km}$ from the contact. The aureoles of other Type D intrusions [15] contain only fibrolitic sillimanite, some of which may have resulted from the intrusion but which is difficult to distinguish from that produced during the late stage of regional metamorphism. The northern contact of the Skiff Lake Granite [30] contains fibrolite, cordierite and andalusite. In the Southern Plutonic Belt, the Tower Hill Granite [31] has imposed an andalusite-staurolite-almandine assemblage on greenschist facies country rock.

The relative amounts of biotite and primary muscovite vary, with leucocratic phases having been observed in [15], [18] and [31]. Garnetiferous pegmatite is abundant in $[18,24,30$ and 31$]$; xenocrysts of andalusite, in [18]; and altered cordierite, in [15]. A mafic dike intrudes [18].

These plutons range from granodiorite to granite, even within the same body (see analyses 24a, b; Fig. 3): The less felsic compositions are chemically indistinguishable from the average compositions of the closely associated megacrystic Type $F$ granites (see analyses $14 \mathrm{a}, \mathrm{b}$; Fig. 3) whereas the more felsic phases are distinctly more aluminous than the other granite types (Fig. 3b, Table 3).

Type $F$

Megacrystic granitoid plutons $[14,29,37]$

The megacrystic granitoids form a texturally distinct group of plutons characterized by $2-8 \mathrm{~cm}$ phenocrysts to subphenocrysts of potassium feldspar and/or plagioclase. Although minor phases containing muscovite have been observed along the borders [29] or within the pluton [14], these plutons are essentially biotite $t$ hornblende-bearing.

The contact aureole of the North Pole intrusion [14] against greenschist facies country rock contains alkali feldspar, cordierite and andalusite with sporadic fibrolite along the south contact. The western contact aureole of the Hawkshaw Granite [29], developed in Cambro-ordovician strata and containing minor fibrolite, is similar in grade, but the eastern contact aureole, developed in Silurian greywacke, reaches only albite-epidote hornfels grade. This suggests that the grade of contact metamorphism was controlled by the thermal conditions in the country rock; i.e., the Miramichi Massif had uplifted relative to the Fredericton Trough and was hotter at the time of intrusion. The very poorly exposed McDougall Lake Granodiorite [37] contains cordierite- and andalusite-bearing rafts.

An interesting feature of these megacrystic granitoids is that the modal ratios of alkali feldspar to plagioclase apparently have considerable variation independent of chemical composition (Martin 1966, McKenzie and Clarke 1973) indi- 
cating that crystallization conditions within these plutons varied.

Type $H$

Equigranular biotite granites

$[20,21,22,32,34,38]$

The high-level coarse-grained biotite granite plutons contain smaller volumes of quartz feldspar porphyry, miarolitic cavities, and minor granophyre. The porphyritic phases are in gradational contact with the coarsegrained host and have been interpreted to represent residual magma mobilized during a late stage degassing event. The miarolitic cavities are believed to be the result of late $\mathrm{H}_{2} \mathrm{O}$ saturation of an initially undersaturated magma (Cherry 1976). The mineralogical and chemical character of all textural facies is of low pressure, minimum temperature melt composition. Local secondary muscovite, muscovite-bearing veins, and muscovite-greisen are attributed to hydrothermal activity. A few of these characteristics occur in the Type B plutons (granophyre, porphyry and miarolitic cavities) indicative of their high level of emplacement. However, these differ from the Type $\mathrm{H}$ biotite granites in their relatively more mafic mineralogic and chemical compositions (Fig. 3) and their spatial association with basic to intermediate rocks.

Types $E$ and $G$

The 'transitional' granite types

$E:[19] ; G:[4,6,10,12]$

The Juniper Barrens Granite [19] is a medium-grained equigranular to subporphyritic biotite granite with an eastern margin about $1 \mathrm{~km}$ wide which is composed of an xenolith-rich biotite-hornblende granodiorite. The margin is veined by biotite-muscovite granite, tourmaline-muscovite granite and garnet-muscovite pegmatite. With these attributes, the Type E Juniper Barrens Granite has characteristics of Types D, F and $\mathrm{H}$ granites.

The Type $G$ granites $[4,6,10,12]$ are located in the northernmost and least uplifted part of the Miramichi Massif and in the Elmtree Inlier. Contact metamorphism has produced cordierite, andalusite and biotite in the cambroordovician rocks and biotite hornfels in the Silurian and Devonian rocks. A mafic dike intrudes the Pabineau Falls pluton [6]. Collectively the textural and mineralogic characteristics of these plutons are similar; medium- to coarse-grained, equigranular biotite granite with local megacrystic phases in the Pabineau Falls Pluton [6], local miarolitic cavities, and variations in feldspar ratios and colour index which ranges between those characteristic of Types $F$ and $H$ granitoids. This attribute is also evident in the available chemical analyses (Fig. 3). The Mount Elizabeth Granite [10] is particularly instructive in this regard. The composition varies from a biotite granite (trans-granodiorite) in the east (analysis 10c, Table 3), gradationally (10b) to a one feldspar, hornblende granite (10a) at its western extremity. Quartzfeldspar dikes (10d) along the western margin of the pluton have more mafic compositions than the one feldspar granite that they intrude.

\section{RELATIVE AND RADIOMETRIC AGES}

The older Granitoids in the Miramichi Massif were deformed with the felsic volcanics of the Ordovician Tetagouche Group during the Taconian orogeny and are interpreted to be related to the same magmatic event. The larger intrusions of older granite form 
TABLE I

Dote relevont to the ages of Acodion Plutons

o) Intrude polydd formed Combro- Ordovicion strota discordan II
$[4,6,8,9,11,13,17,19,21,22,26,27,28,31,32,35]$

b) Intrude Older Granitiod Bodies:
$\left[10,12,14^{*}, 15,18,19,20^{\circ}, 24\right]$

c) Intrude Silurion or Lower Devonion strato:
$\left[1,2,3,5,7,10 ; 16^{+}, 23,29,30^{*}, 33,34^{+}, 36^{+}, 37,38,39,40\right]$

Weok fabric but contoin inclusions with Toconion fobric

"Numbers identify plutons on Figure

${ }^{+} \mathrm{Rb}$ - $\mathrm{Sr}$ whole-rock isochron oges, see Figure

\section{TABLE 2}

Relotionships between matic and felsic intrusions

a) Mafic plutons intruded by felsic plutons:

$\begin{array}{cc}\text { Mofic } & \text { Felsic } \\ {[33]} & {[4]} \\ {[8,9,1]} & [1]] \\ {[17]} & {[16]} \\ {[23]} & {[2]} \\ {[35]^{+}} & \text {Boring Gronite (Maine) }\end{array}$

b) Composite intrution
$\left[2,36^{+}, 40\right]$

c) Felsic intrusions

d) Felsic intrusions or phoses cut by matic dikes

(documented, probable) reaction between gabbro ond
loter felsici mogmo which produced hybrid rocks of
intermediate composition

\section{FIGURE 3a}

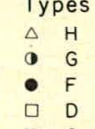

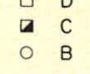

South Mountain Batholith

South Mountoin
adanodiorite
adamellite

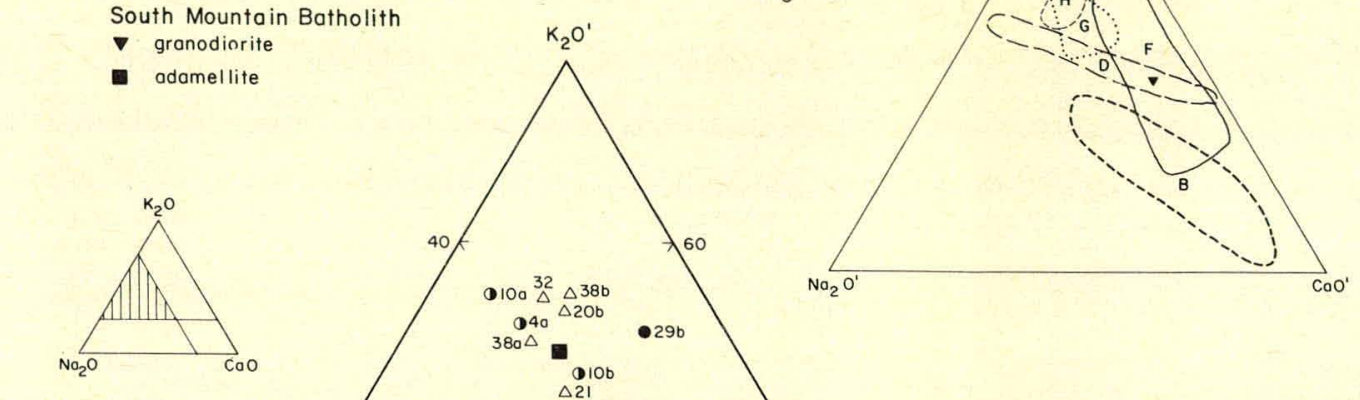

TABLE 3

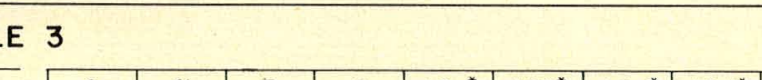

\begin{tabular}{|l|c|c|c|c|c|c|c|c|}
\hline $\begin{array}{l}\text { Index } \\
\text { Number }\end{array}$ & $4 a$ & $4 b$ & 5 & 6 & $100^{*}$ & $100^{*}$ & $100^{*}$ & $100^{*}$ \\
\hline Type & $G$ & 6 & 8 & 6 & 6 & & 14 \\
\hline
\end{tabular}

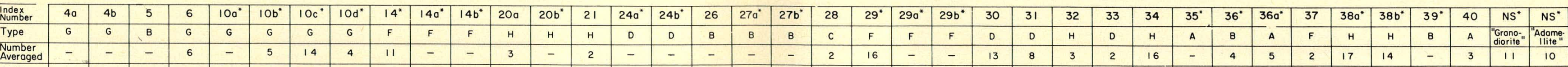

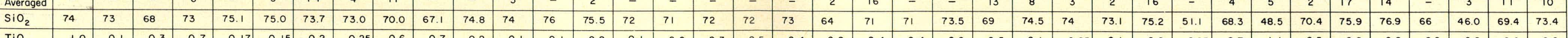

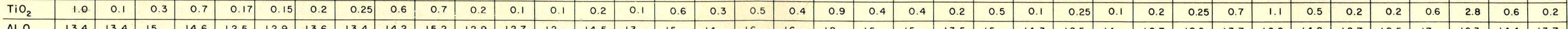

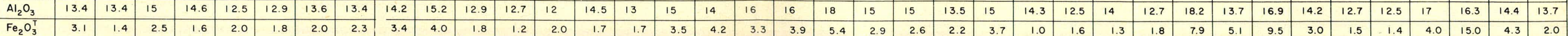

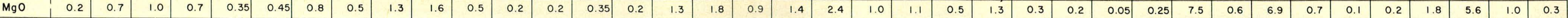

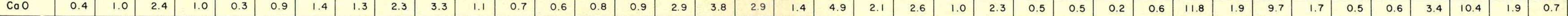

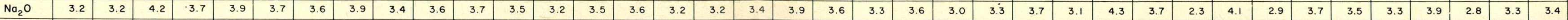

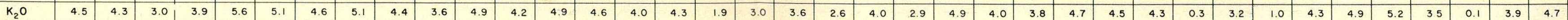

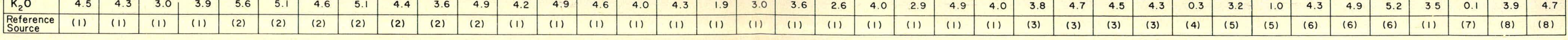

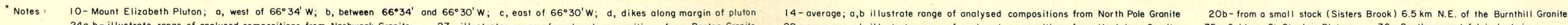

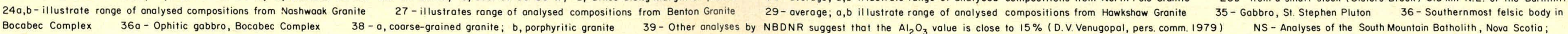

Reference (1) Martin (1966); dato republished in Crocco (1975). (2) Deportment of Natural Resources, New Brunswick. 
elongate bodies which concordantly follow changes in the direction of the regional fabric and stratigraphy (Fig. 1). These preTaconian plutons have yielded RbSr whole rock ages of $479 \pm 14$ and $432 \pm 6 \mathrm{Ma}$ and $484 \pm 33 \mathrm{Ma}$ (Fyffe et al. 1977, R.F. Cormier, pers. comm. 1979, Poole 1980). The youngest age was obtained from an intrusion which had undergone high-grade metamorphism which overprints the Taconian fabric and may therefore represent a 'modified' age.

The character and age of the country rocks intruded by the Acadian Plutons are summarized in Table 1. In the Central Plutonic Belt, these plutons were intruded after the Acadian deformation of the Matapedia Basin and the Fredericton Trough, and after considerable movement on the faults which bound and segment the Miramichi Massif (Fig. 1). Plutons which intrude the faults $[16,17$, $18,19,21,23,24,29]$ possess local mylonite zones which resulted from continued movement along these faults. Some of the faultstraddling intrusions $[17,19,29]$ have lower grade contact aureoles against the Siluro-Devonian rocks of the Basin and the Trough than against the older rocks of the Miramichi Massif. This strongly suggests that movement on these faults had juxtaposed hotter Massif rocks against somewhat cooler Basin and Trough rocks prior to intrusion of the plutons. Some Acadian plutons within the Massif possess a fabric developed during or shortly after emplacement [25, 281 (Type C); have appendages or proximal dikes which are concordant with the latest tectonic fabric and/or possess a border fabric [14, 15] (Types D, F) or are variably elongated parallel to the regional fabric $[15,18$, $24,29]$ (Types D, F). These features indicate that these plutons were intruded during the orogenic stage of waning active strain through to the subsequent condition of directed residual stress. The presence of xenoliths containing the Taconian fabric in the locally mylonitized clearwater Gabbro [17] and in the fabricbearing Hartfield Tonalite [28] attest to their Acadian affinities. other plutons within the Massif $[4,6,10,12,20,21,22]$ (Types $G, H)$ have traditionally been ascribed to be post-orogenic, i.e., intruded into terrain apparently free of directed stresses.

Therefore, the earliest phase of the Acadian intrusive event in the Central Plutonic Belt was coeval with the latest stages of Acadian tectonism; spetificaliy after the adjacent Fredericton Trough and Matapedia Basin were deformed and cleaved, but before cooling had equalized temperatures across the faults bounding the Miramichi Massif, and before tectonic strain had completely ceased within the Massif. Plutonism in the Southern Plutonic Belt was approximately synchronous and of similar pattern.

Within the mainly bimodal character of the Acadian plutons in both Plutonic Belts there is consistent evidence that the bulk of the mafic magma (Type A) was intruded earlier than the more voluminous felsic magma, although the time interval in some instances may have been short. Since only a few of the felsic intrusions are cut by basic dikes, we believe that there was a short period of overlap between the intrusions of the mafic and the earliest felsic magmas (Type B). The specific observations leading to these conclusions are summarized in Table 2 .

A $\mathrm{Rb}-\mathrm{Sr}$ whole rock isochron from the Type B Redstone Mountain Granite [16] yielded a $409 \pm 20 \mathrm{Ma}$ 
age (Fyffe and Cormier 1979), which is almost identical to an isochron age of $403 \pm 20$ Ma obtained from the Type B felsic rocks of the Bocabec Complex [36] (Pajari et al. 1974; revised age $\mathrm{R}$. F. Cormier, pers. comm. (1979). Both plutons intrude mafic plutonic rocks and cleaved early Devonian (Gedinnian) strata. Relative to the regional $405-410 \mathrm{Ma}$ age for the Silurian - Devonian boundary (Fyffe and Cormier 1979), these two felsic intrusions define an early Devonian age for the slightly older mafic plutons (Table 2), which intrude cleaved SiluroDevonian strata. In two cases, the felsic plutons that are intimately associated with the mafic plutons have been shown to have intruded hot gabbro (Fyffe 1971, Butt 1976), suggesting a relatively short interval between the intrusion of these types.

Granodiorite from one of the Type B Charlo Stocks has yielded a whole rock age of $370 \pm 30 \mathrm{Ma}$ (Stewart 1979).

Evidence for the relative or absolute ages of other individual Acadian plutons is not abundant, but the data do establish consistent relationships between some of the types of intrusions.

All of the muscovite-bearing Type D granites in the Massif $[15,18$, $24,30]$ are associated with relatively extensive high-grade aureoles. Since these aureoles are characteristically more extensive than those of other plutons within the Massif, the muscovite-bearing intrusions are interpreted to have been emplaced at greater depth into relatively hotter country rock. Butt (1976) has argued that the muscovite-bearing Tower Hill Granite [31] in the Southern Plutonic Belt must be an early intrusion because it had crystallized under higher pressure, hence deeper, than the nearby biotite granites $[32,34,38]$ (Type $H$ ) now exposed on the same erosion level. The Nashwaak Granite [24] intrudes the Becaguimec Lake Gabbro [23], and associated felsic intrusions suggesting that the muscovitebearing granites (Type $D$ ) are younger than the Type $A$ and $B$ intrusions.

The megacrystic Type $F$ Hawkshaw Granite [29] intrudes the muscovite-bearing Type D Skiff Lake Granite [30] (Lutes 1979), whereas the megacrystic North Pole Granite [14] appears to be gradational into the northern portion of the muscovite-bearing North Dungarvon Granite [15].

The fact that the Hawkshaw and Skiff Lake Granites have a nearly equal grade of contact metamorphism against the Massif precludes a long interval between their intrusion. A $378 \pm 7 \mathrm{Ma}$ whole rock isochron (R.F. Cormier, pers. comm. 1979) from the megacrystic North Pole Granite and $389 \pm 20 \mathrm{Ma}$ whole rock isochron (McCutcheon et al. in prep.) from the skiff Lake Granite corroborates the suggestion that the megacrystic (Type F) and closely related muscovitebearing Type $D$ granites are younger than the mafic and felsic intrusions of Types $A$ and $B$.

The biotite-bearing Type $\mathrm{H}$ 'postorogenic' granites generally form equidimensional intrusions, frequently with high-level characteristics such as granophyre and/or miarolites and moderate to lowgrade metamorphic aureoles. Dikes believed to be coeval with the Type H Burnthill Granite [20] cut the muscovite-bearing Type D Lost Lake Granite [18]. The Burnthill Granite has yielded a whole rock age of $352 \pm 9 \mathrm{Ma}$ (C. Brooks, pers. comm. 1980). Butt (1976) and Cherry (1976) have presented arguments suggesting a high-level em- 
placement for the Type H Granites of the Southern Plutonic Belt, one of which [34] has yielded a Carboniferous age of $337 \pm 15 \mathrm{Ma}$ (R.F. Cormier, pers. comm. 1978). They are undoubtedly the youngest intrusions.

The legend of Figure 1 is an attempt to establish a chronological intrusive sequence based on a framework of Types A, B, D. $F$ and $H$ described above. The weakly foliated plutons $[25,28]$ of Type $C$ are mineralogically similar to the Type $B$ intrusions and are somewhat more strained than the Type D muscovite-bearing granites. Therefore, these have been assigned an intermediate age. Similarly, the remaining types, $E$ and $G$, are tentatively allocated legend positions based on their resemblance to granites in the more firmly established sequence.

\section{GENETIC SPECULATIONS AND COMPARISONS}

The Acadian plutons appear to form a sequence of intrusions that range from early Devonian to Carboniferous in age. We take the previously described evidence of spatial association, compositional similarities and/or compositional variation between or within plutons in its simplest context to suggest that there was no significant break in the evolution of the Acadian plutonic event. This event began with the intrusion of mantle-derived magma (Type A) along regional faults. The closely associated felsic plutons (Type B) were probably generated by the heat energy provided by the mafic magma - a generative mechanism which could account for the rather more mafic compositions of the Type $B$ intrusions, in that the sudden influx of heat energy is likely to create rapid and relatively local melting.
In time, and with the addition of heat energy from radioactive decay in the crust previously thickened during the Taconian orogeny, the temperature in the crustal rocks so affected would increase and become more uniform. This type of condition would be necessary for the generation of large volumes of granitic melt that would in time more closely approach an end product of a minimum melt. Within the evolution of New Brunswick Acadian plutonism, this kind of gross pattern is evident (Fig. 3 ).

The genetic controls of the more specific variations between and within the various types of intrusions are undoubtedly complex, but would include broad factors such as depth of intrusion, volatile concentration, degree of differentiation and mixing (sensu zato) Part of the variation in individual Type $B$ plutons is attributable to reaction between mafic rocks and felsic magma, but other mechanisms may have been operative. The relatively deep level muscovite-bearing granitoids (Type D) were probably restricted in their upward migration by volatile saturation, a fact which is consistent with their relatively early appearance in the magmatic sequence. Melting and/or differentiation under high pressure, water saturated conditions could account for the difference in the more felsic variants of this type compared to Types $G$ and $H$ (Fig. 3 ).

The remaining Types $\mathrm{F}, \mathrm{G}$ and $\mathrm{H}$ were apparently more water undersaturated (perhaps progressively so) and form a series of types within which compositional variation within plutons decreases from $F$ to $H$. Evidence cited previously from the Type $G$ Mount Elizabeth Pluton [10] indicates that differentiation was probably effective there and, by implication 
perhaps in other cases. In contrast, the total compositional variation in the large type $H$ Charlotte Pluton [38] is barely detectable (Cherry 1976). However, it should be noted that the average composition, irrespective of considerations of variability, appears to change progressively through Types $F, G$ and $H$ toward more felsic and potassic compositions, suggesting that chemical evolution was controlled by melting conditions.

A comparison of these plutonic rocks with those of Newfoundland (Strong 1979) reveals a nearly parallel classification of 1) mafic-silicic plutons, 2) microcline megacrystic biotite granites, 3) two-mica leucogranites and 4) metaluminous to peralkaline granites. Equivalents in our New Brunswick classification are 1) Types A, B; 2) Type F; 3) Type D and 4) Types $G$ and $H$ ). In Newfoundland, however, the pluton types are restricted to specific tectonic zones, a correlation which is not as evident in New Brunswick.

Similarly, the South Mountain Batholith of Nova Scotia is partly equivalent texturally and compositionally to rocks in New Brunswick. The Nova Scotia "Granodiorite" is identical to the Type F granitoids, but the later two-mica "Adamellite" is outside the compositional field for New Brunswick Type D granites (Fig. 3). Clarke (pers. comm. 1979) has suggested on considerable evidence that the Nova Scotia "Adamellite" is a fractionate from the more voluminous granodiorite magma. This could account for its compositional similarity to the Type $G$ and $H$ New Brunswick granites, perhaps requiring only a greater depth of crystallization to effect the appearance of muscovite.
This brief comparison serves to illustrate the difficulty of documenting plutonic activity on an orogen-wide basis and the level of knowledge necessary to succeed - a level not yet attained.

\section{CONCLUSIONS}

The lack of compositional polarity, a largely bimodal character and a common evolutionary trend irrespective of geography, rule out a direct relationship between New Brunswick Acadian plutonism and a subduction related mechanism. specifically, the existence of a second post-Taconian, pre-Carboniferous subduction zone south of the province (Poole 1976, Ruitenberg et $a$. 1977) is not supported by the plutonic rocks as the evolution of magmatism was identical and coeval in both the central and Southern Plutonic Belts. Since the Acadian plutonic event followed the Taconian continental collision by some tens of millions of years, a time dependent process such as radioactive heating of a thickened crust must have been a critical factor.

The Acadian intrusive rocks of New Brunswick appear to be related to a single cycle which followed the closing of the Iapetus ocean. since the character of this plutonism is not readily comparable to any orthodox continental margin model, we may be witnessing the emergence of a presently unique Appalachian type model.

\section{ACKNOWLEDGEMENTS}

L.R.F. wishes to acknowledge the financial support of the New Brunswick Dept. of Natural Resources and the Canada Dept. of Regional Economic Expansion and the field assistance of C.J. St. Peter, G. G. Lutes, D. V. Venugopal, R.R. Irrinki and G. Crouse. G.E.P. acknowledges the financial support 
of G.S.C. and N.R.C. Grants during various stages of the study of. New Brunswick granites. This represents Canadian Contribution No. 22 to I.G.C.P. Project 27. We thank Ron Phillips for preparing the figures and tables and AnnaMarie Brown for typing the manuscript.

BENNETT, G. 1965. The petrology of the Stewarton igneous complex. M.Sc. thesis, University of New Brunswick, Fredericton, New Brunswick, 105p.

BIRD, J.M. and DEWEY, J.F. 1970. Lithosphere plate - continental margin tectonics and the evolution of the Appalachian orogen. Geological Society of America Bulletin, 81, pp. 1031-1060.

BUTT, K.A. 1976. Genesis of granitic stocks in southwestern New Brunswick, $\mathrm{Ph}$. D. thesis, University of New Brunswick, Fredericton, New Brunswick, 234p.

CHERRY, M.E. 1976. The petrogenesis of granites in the St. George Batholith, southwestern New Brunswick, Canada. $\mathrm{Ph} . \mathrm{D}$. thesis, University of New Brunswick, Fredericton, New Brunswick, 242p.

CROCCO, P.E. 1975. A summary report on the granitic rocks of New Brunswick. New Brunswick Department of Natural Resources, Mineral Resources Branch, Topical Report 75-6; 150p.

DUNHAM, K.C. 1959. Petrography of the nickeliferous norite of St. Stephen, New Brunswick. American Mineralogist, 35, pp. 711-727.

FYFFE, L.R. 1971. Petrogenesis of the adamellite-diorite transition, southwestern New Brunswick. M.Sc. thesis, University of New Brunswick, Fredericton, New Brunswick, 130p.

1976. Correlation of geology in the southeastern and northern parts of the Miramichi Zone. In 139th Annual Report, New Brunswick Department of Natural Resources, pp. 137-141.

FYFFE, L.R., IRRINKI, R.R. and CORMIER, R.F. 1977. A radiometric age of deform- ed granitic rocks in north-central New Brunswick. Canadian Journal of Earth Sciences, 14, pp. 1687-1689.

FYFFE, L.R. and CORMIER, R.F. 1979. The significance of radiometric ages from the Gulquac Lake area of New Brunswick. Canadian Journal of Earth Sciences, 16, pp. 2046-2052.

HEMLSTAEDT, H. 1971. Structural geology of Portage Lakes area, Bathurst-Newcastle district, New Brunswick. Geological Survey of Canada, Paper 70-28, $52 \mathrm{p}$.

LUTES, G.G. 1979. Geology of Fosterville - North and Ee1 Lakes (map-area G-23) and Canterbury - Skiff Lake (maparea $\mathrm{H}-23)$, New Brunswick Department of Natural Resources, Mineral Resources Branch, Map Report 79-3, 22p.

MARTIN, R.F. 1966. A chemical and petrographic study of the granitic rocks of New Brunswick, Canada. M.Sc. thesis, Pennsylvania State University, University Park, Pennsylvania, 120p.

McCUTCHEON, S.F., LUTES, G., GAUTHIER, G. and BROOKS, C. The Pokiok Batholith: a contaminated Acadian intrusion with an anomalous $\mathrm{Rb}-\mathrm{Sr}$ age. Canadian Journal of Earth Sciences (in preparation).

MCCUTCHEON, S.F. and RUITENBERG, A.A. The geology and mineral deposits of the Annidale-Nerepis area, New Brunswick Department of Natural Resources, Mineral Resources Branch, Report of Investigation (in preparation).

NEUMAN, R.B. 1968. Paleogeographic implications of Ordovician shelly fossils in the Magog Belt of the northern Appalachian Region. In Studies of Appalachian Geology - Northern and Maritime. Edited by E-An Zen, W.S. White, J.B. Hadley and J.B. Thompson, Jr., John Wiley and Sons, New York, N.Y., pp. 35-48.

PAJARI, G.E., Jr., TREMBATH, L.T., CORMIER, R.F. and FYFFE, L.R. 1974. The age of the Acadian deformation in southwestern New Brunswick. Canadian Journal of Earth Sciences, 11, pp. 1309-1313. 
PAJARI, G.E., Jr., RAST, N. and STRINGER, P. 1977. Paleozoic volcanicity along the Bathurst-Dalhousie geotraverse, New Brunswick, and its relations to structure. In W.R.A. Baragar, L.C. Coleman and J.M. Hall (Editors), Volcanic Regimes in Canada. Geological Association of Canada, Special Paper 16, pp. 111-124.

POOLE, W.H. 1976. Plate tectonic evolution of the Canadian Appalachian Region. In Report of Activities, Part B. Geological Survey of Canada, Paper 76-1B, pp. 113-126.

1980. $\mathrm{Rb}-\mathrm{Sr}$ ages of the "sugar" granite and Lost Lake Granite, Miramichi Anticlinorium, Hayesville map area, New Brunswick. Current Research, Part C. Geological Survey of Canada, Paper 80-1C, pp. 174-180.

RAST, N. and STRINGER, P. 1980. A geotraverse across a deformed Ordovician ophiolite and its Silurian cover, northern New Brunswick, Canada. Tectonophysics, 69, Pp. 221-245.

RODGERS, J. 1970. The tectonics of the Appalachians. John Wiley and Sons, New York, N.Y. 271p.

RUITENBERG, A.A., FYFFE, L.R. ,MCCUTCHEON, S.R., ST. PETER, C.J., IRRINKI, R.R. and VENUGOPAL, D.V. 1977. Evolution of pre-Carboniferous tectonostratigraphic zones in the New Brunswick Appalachians. Geoscience Canada, 4, pp. 171-181.

SCHENK, P.E. 1971. Southeastern Atlantic Canada, northwestern Africa and con- tinental drift. Canadian Journal of Earth Sciences, 8, pp. 1218-1251.

STEWART, R.D. 1979. The geology of the Benjamin River Intrusive Complex. M.Sc. thesis, Carleton University, Ottawa, Ontario, 126p.

ST. JULIEN, R. and HUBERT, C. 1975. Evolution of the Taconian Orogen in the Quebec Appalachians. American Journal of Science, 275A, pp. 237-262.

ST. PETER, C.J. 1978. Geology of parts of Restigouche, Victoria and Madawaska counties, northwestern New Brunswick. New Brunswick Department of Natural Resources, Mineral Resources Branch, Report of Investigations 17, 69p.

STRONG, D.F. 1979. Tectonic control of contrasting Paleozoic granitoid plutons around the North Atlantic. In Abstracts, The Caledonides in the U.S. A., International Geological Correlation Program Project: Caledonide Orogen. Edited by D.R. Wones, p. A8.

WONES, D.R. 1976. The Penobscot Bay Area of Maine. In Field Guide to the Geology and Plutonic Rocks of southwestern New Brunswick and the Penobscot Bay Area of Maine. Edited by G.E. Pajari, Jr. International Geological Correlation Program, Canadian Plutonics Study Group, Project Caledonian Orogen, 1, pp.39-69.

WONES, D.R. and STEWART, D.B: 1976. Middle Paleozoic regional right-lateral strike-slip faults in central coastal Maine. Geological.Society of America, Abstracts with Programs, 8, p. 304. 